Why Financial Structure Matters

Joseph E. Stiglitz

The Journal of Economic Perspectives, Vol. 2, No. 4. (Autumn, 1988), pp. 121-126.

Stable URL:

http://links.jstor.org/sici?sici=0895-3309\%28198823\%292\%3A4\%3C121\%3AWFSM\%3E2.0.CO\%3B2-A

The Journal of Economic Perspectives is currently published by American Economic Association.

Your use of the JSTOR archive indicates your acceptance of JSTOR's Terms and Conditions of Use, available at

http://www.jstor.org/about/terms.html. JSTOR's Terms and Conditions of Use provides, in part, that unless you have obtained prior permission, you may not download an entire issue of a journal or multiple copies of articles, and you may use content in the JSTOR archive only for your personal, non-commercial use.

Please contact the publisher regarding any further use of this work. Publisher contact information may be obtained at http://www.jstor.org/journals/aea.html.

Each copy of any part of a JSTOR transmission must contain the same copyright notice that appears on the screen or printed page of such transmission.

JSTOR is an independent not-for-profit organization dedicated to and preserving a digital archive of scholarly journals. For more information regarding JSTOR, please contact support@jstor.org. 


\title{
Why Financial Structure Matters
}

\author{
Joseph E. Stiglitz
}

$\mathbf{T}$ he 1958 paper by Franco Modigliani and Merton Miller has been justly hailed as a landmark in the modern theory of finance. What has not been sufficiently emphasized is the importance of the paper to the development of economic theory and practice. Indeed, it is ironic that a paper which purportedly established that one need not pay any attention to financial structure-that financial structure was irrelevant-should have focused economists' attention on finance. Merton Miller gives what must be part of the explanation in his preceding paper in this issue: by providing conditions where financial policy was irrelevant, conditions which were close to the assumptions used by most conventional economists, the paper forced a reexamination of those standard assumptions. That reexamination is still going on.

The MM results have such great intellectual power and appeal that their direct effect has sometimes been to lead economists astray. This result may perhaps be seen most forcefully in the work in investment theory. In the major study done prior to MM, that of Meyer and Kuh (1959), financial variables (like profitability) were identified as having important independent effects on investment. But the paradigm that became dominant following the publication of MM, most forcefully articulated by Dale Jorgenson and his associates, argues that in the absence of taxation, financial structure (for instance, the magnitude of the firm's equity base) or cash flow would make no difference to the level of investment. Theory drove the econometrics: financial structure variables were excluded because "economic theory"- that is, Modigliani and Miller - said they should be excluded. Only recently, as a developing and substantial body of economic theory says once again that such variables should be included, have econometricians included profit variables again in their specifications

- Joseph E. Stiglitz is Professor of Economics, Stanford University, Stanford, California. 
of the causes of investment. And lo and behold, they appear to be significant! One of the lessons to be learned here is that economists should be careful in being overly dogmatic in the theoretical strictures we impose on our econometric models. Though it may be going too far to advocate "letting the data speak for itself" without any theoretical guidance, economists should at least be attentive to those whispers which the data occasionally emit.

Again ironically, some of the most productive responses to the MM results have come from those who did not feel able to accept the conclusion that financial policy is irrelevant. The MM results forced these skeptics to identify which of the assumptions underlying the MM theorem should be modified or rejected. The attention of economists during the past 30 years has focused on four assumptions underlying the model: first, that firms can be identified by "risk class;" second, that individual borrowing can substitute for firm borrowing; third, that investors have full information about the returns of the firm; and fourth-the importance of which MM themselves recognized-is that there are no taxes, or at least tax policy does not treat debt and equity differentially. The question has been not so much whether these assumptions are "realistic," but whether, or under what circumstances, altering these assumptions leads to situations where financial structure does indeed matter.

\section{The Risk Class Assumption}

The assumption that each firm could be sorted into a "risk class" was a simplification which turned out to be enormously useful in other areas. But strangely enough, it turned out that the risk class assumption-and the associated arbitrage argument-could be completely dispensed with and the validity of a more general proposition on the irrelevance of financial structure, within a general equilibrium context, could easily be established, provided only that firms do not issue so much debt that they incur a positive probability of bankruptcy (Stiglitz, 1969). The restated theorem asserted simply that, if there is an equilibrium with a firm having a particular debt-equity ratio and market value, there exists another equilibrium with the firm having any other debt-equity ratio, and in that new equilibrium the firm has the same market value as it did in the original equilibrium. ${ }^{1}$

This result shifted the focus of attention from the idea of the risk class to the importance of bankruptcy. The market does seem to be concerned about bankruptcy; after all, interest rates charged even the best of firms exceed by a considerable amount the rates paid by the government. Yet the fact that bankruptcy is important, in this sense, does not necessarily invalidate the relevance of the revised MM theorem. Economists have tried to spell out models where a chance of bankruptcy exists, but financial policy remains irrelevant. For instance, if the returns of all firms were

\footnotetext{
${ }^{1}$ In a subsequent paper (Stiglitz, 1974), it was shown that not only did the firm's choice of debt-equity ratio not matter, but neither did its dividend payout ratio, the maturity structure of its debt, nor any other aspect of its financial policy.
} 
(jointly) normally distributed and all individuals had quadratic, constant absolute risk aversion, or constant relative risk averse utility functions, or if there were a sufficient number of securities so that the value of income in each state of nature (each outcome) was determined independently of what the firm did, then the financial irrelevance proposition would still be valid.

But none of these "special" models has gained broad acceptance, because each of them has some unrealistic implications. For instance, what firm managers mean by risk does not accord well with how the models predict managers should use the term; in these models, the only aspect of risk which is important is how an individual firm correlates with the market return, but firm managers also care about the variance of the return. What is at issue is not just a matter of semantics: the information that firms gather for decision making is based on their view of the appropriate concept of risk. $^{2}$ Moreover, most of these models also argue that the value of the firm is proportional to its scale, or equivalently that firms do not face downward sloping demand curves for their shares. Again, several studies have at least called into question the empirical validity of that hypothesis.

\section{Homemade Leverage}

A second assumption which entered both the original MM presentation and subsequent generalizations was that individual borrowing, or homemade leverage, was a perfect substitute for firm borrowing. This assumption seemed to contradict the obvious fact that many individuals were constrained in the amount of credit they could get, and in any case could not borrow at the same terms that firms could. Much of the subsequent finance literature ignored the possibility of individuals being credit-constrained, not because of the empirical evidence showing that such constraints did not exist, but again because of theoretical considerations: in a perfect competitive capital market, such constraints simply could not exist. There were voices in the wilderness - James Tobin comes to mind - who contended that credit constraints were important, but they were not listened to until theory provided a rationale for such constraints.

\section{Full Information about Returns}

It is often the unstated rather than the stated assumptions of a model which are critical, and so it is in the case of the MM theorems. A critical unstated assumption is that all market participants have full and equal information concerning the returns to the firm. However, the existence of asymmetric information gives rise to two problems:

\footnotetext{
${ }^{2}$ There are other problems, particularly with the mean-variance models. For example, they "predict" that all individuals purchase the same mix of risky securities and that individuals should hold widely diversified portfolios, two predictions that seem to be contradicted by the facts.
} 
current owners may wish to convince potential borrowers that the firm is worth more; and managers can take actions which affect the returns to those who provide capital. In the simple early models where everyone has full information, debt and equity differed only in the sort of risk they involved. In the world of imperfect information they differ in a number of other respects: since the amount that suppliers of debt receive is fixed, except in states of bankruptcy, debt does not require monitoring total returns; all that is required is monitoring actions which affect bankruptcy, and monitoring income in bankruptcy states. The fact that equity is widely dispersed, while debt (partly because of its risk characteristics) can be more closely held means that the free rider problems associated with ensuring that managers take actions in the interests of equity holders are greater than the corresponding problems of ensuring that managers take actions in the interests of debt holders; as a result, it has been argued that debt holders may exercise more effective control over capital than equity holders.

Managerial incentives are markedly different with debt and equity contracts. Debt imposes a threat of bankruptcy on managers, a threat which advocates of what Robert Hall has called the "backs-to-the-wall" approach to corporate finance believe will have a positive effect on managerial incentives. By the same logic, debt and equity contracts have very different effects on managerial risk taking.

Because of these and other differences between debt and equity, a firm's choice of financial structure may convey information about the firm's prospects to potential lenders and purchasers of equity. Theoretical models have been constructed to show why equity issues may be interpreted as a negative signal, and empirical evidence confirms their depressing effect on price. ${ }^{3}$ Owners who have inside information and know that the market has overvalued their shares are more willing to sell shares than those who know that the market has undervalued their shares. Managers who know that their true net worth position is favorable may be willing to signal that through larger cash distributions to shareholders. Managers who know that there is little prospect of bad outcomes may be willing to signal that knowledge by undertaking more debt.

These considerations of adverse selection and moral hazard have been used to explain why firms may be credit-rationed (Stiglitz and Weiss, 1981, 1983; Keeton, 1978) or equity-rationed. But these forms of financial constraints are but extreme examples, demonstrating clearly that the financial structure of firms can make a difference. Theories of optimal financial structure can be derived, with the optimal structure depending on the nature of the information problems being faced.

\section{Tax Differentials}

A final set of circumstances in which financial structure may matter relates to the existence of taxes. Debt and equity are treated by tax authorities in markedly different

\footnotetext{
${ }^{3}$ For theoretical discussions, see Leland and Pyle (1977), Ross (1977), Stiglitz (1982), Greenwald, Stiglitz, and Weiss (1984), and Meyers and Majluf (1984). For a discussion of empirical evidence, see Asquith and Mullins (1983).
} 
ways. While the fact that debt payments are deductible under the corporation tax might seem to give debt an advantage over equity, one needs to look at the total tax consequences - at the combined effects at the individual and corporate levels. Moreover, the tax laws impose taxes on changes in financial structure. In other words, even if two firms had identical earnings, but one had a higher debt and lower total tax liabilities, it might still not pay for the other firm to change its financial structure. To increase its debt-equity ratio, after all, the second firm must pay out money to its equity holders (borrowing to pay dividends or buy back shares), and there is thus a cost of transition - the tax on the dividends, or the capital gains tax on the share repurchase - which must be set against the steady state gains.

What is required is a full, dynamic analysis ${ }^{4}$ of firm financial structure, incorporating both corporate and individual taxation, of the kind I presented in my 1973 paper. There, I showed that for tax rates of the kind that had prevailed up to that time, while debt had a slight steady state advantage over equity, this advantage was not so great as to make financial restructuring desirable. In general, it did not pay firms that had small debt-equity ratios, as a result of a series of high returns on previous investments, to increase their debt-equity ratio. If their demand for investment exceeded their retained earnings, it was optimal for them to raise the additional funds required through debt. The fact that there is, in effect, a tax on financial restructuring means that there is a large historical element in observed capital structures. And it explains why changes in tax laws, such as the 1986 Tax Reform, seem to lead to, at most, limited financial restructuring by most firms.

There remain puzzles. Though one can easily construct a theory in which it pays firms to distribute funds to shareholders to signal the worth of the firm, it is always desirable for firms to do so by repurchasing shares or by cash mergers and acquisitions, rather than by dividend payments. The suggestion that, were all firms to repurchase shares, the IRS might change the rules ${ }^{5}$ is not an explanation for why any single firm issues dividends; and even were it to tax share repurchases, there are other means by which funds may be distributed from the corporate to the household sector and receive favorable tax treatment. Since this paradoxical question of why dividends should be paid at all was first discussed (for example, in my 1973 paper), firms have in fact seemed slowly to learn this lesson to the point where more funds are now distributed in these forms than as dividends. (A paper forthcoming in this journal by John Shoven and Laurie Simon Bagwell documents and discusses this trend.) Yet why were firms so slow to learn this costly lesson, and why have so many firms yet to learn it at all?

\footnotetext{
${ }^{4}$ Such a dynamic analysis must take explicit account of the asymmetries in the tax code. For example, positive cash flows from the corporate sector to the household are taxed, but there is no negative tax on negative cash flows.

${ }^{5}$ Under current tax law, sales of shares back to the firm are treated just like any other sale of shares; the individual pays a capital gains tax on the difference between the sale price and the price he originally paid for the shares. There are a variety of ways by which the tax authorities could discourage share repurchases. Prior to 1986, they could have subjected share repurchases to full taxation, rather than extending the favorable capital gains treatment. They could subject the total purchase price to taxation, not allowing a deduction for the original purchase price.
} 
The fact that the optimal financial structure depends on tax rates, and that different investors face markedly different tax rates means, of course, that different firms should have different clientele. If those versions of the capital valuation model which assert the existence of a large number of similar firms were correct, then there would be some firms which pursued an all debt policy, others an all equity policy, and still others a "historical" policy of the kind described above; within any risk class (to use the MM concept) firms in each category would have distinctly different owners. Though firms may differ somewhat in their clientele, they do not differ in the marked way predicted by the theory.

Modigliani and Miller, in their brilliant papers, have set forth a research agenda which will occupy economists for decades to come. The direction which Modigliani and his co-authors suggest in their recent work, a systematic exploration of market "irrationalities," seems among the most fruitful for enhancing our understanding of these hitherto unexplained quandaries.

\section{References}

Asquith, P. and Millins, D. W., "Equity Issues and Stock Price Dilution," Harvard Business School, unpublished paper, 1983.

Greenwald, B., Stiglitz, J. E., and Weiss, A. "Informational Imperfections in the Capital markets and Macro-Economic Fluctuations," American Economic Review, May 1984, 74:1, 194-99.

Keeton, W., Equilibrium Credit Rationing, New York: Garland Press, 1978.

Leland, H. E., and D. H. Pyle, "Informational Asymmetries, Financial Structure, and Financial Intermediation," Journal of Finance, 1977, 32, 371-87.

Mayer, J., and E. Kuh, The Investment Decision; and Empirical Study. Cambridge: Harvard University Press, 1959.

Myers, S. C., and N. S. Majluf, "Corporate Financing and Investment Decisions when Firms have Information that Investors Do Not," Journal of Financial Economics, 1984, 11, 187-221.

Ross, S. A., "The Determination of Financial Structure: The Incentive Signalling Approach," Bell Journal of Economics, 1977, 8, 23-40.
Stiglitz, J. E., "A Re-Examination of the Modigliani-Miller Theorem", American Economic Review, December 1969, 59:5, 784-793.

Stiglitz, J. E., "Corporate Financial Policy and the Cost of Capital," Journal of Public Economics, February 1973, 2, 1-34.

Stiglitz, J. E., "On the Irrelevance of Corporate Financial Policy," American Economic Review, December 1974, 64, 851-866.

Stiglitz, J. E., "Information and Capital Markets," In Cootner, C., and W. Sharpe, eds., Financial Economics: Essays in Honor of Paul Cootner." Englewood Cliffs, NJ: Prentice-Hall, 1982, 118-58.

Stiglitz, J. E., and A. Weiss, "Credit Rationing in Markets with Imperfect Information," American Economic Review, June 1981, 71:3, 393-410.

Stiglitz, J. E., and A. Weiss, "Incentive Effects of Termination: Applications to the Credit and Labor Markets," American Economic Review, December 1983, 73, 912-927. 
http://www.jstor.org

\title{
LINKED CITATIONS
}

- Page 1 of 2 -

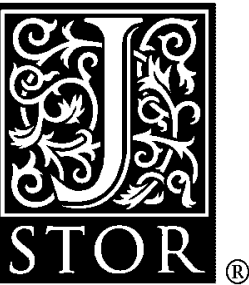

You have printed the following article:

\section{Why Financial Structure Matters}

Joseph E. Stiglitz

The Journal of Economic Perspectives, Vol. 2, No. 4. (Autumn, 1988), pp. 121-126.

Stable URL:

http://links.jstor.org/sici?sici=0895-3309\%28198823\%292\%3A4\%3C121\%3AWFSM\%3E2.0.CO\%3B2-A

This article references the following linked citations. If you are trying to access articles from an off-campus location, you may be required to first logon via your library web site to access JSTOR. Please visit your library's website or contact a librarian to learn about options for remote access to JSTOR.

\section{[Footnotes]}

\author{
${ }^{1}$ On the Irrelevance of Corporate Financial Policy \\ Joseph E. Stiglitz \\ The American Economic Review, Vol. 64, No. 6. (Dec., 1974), pp. 851-866. \\ Stable URL: \\ http://links.jstor.org/sici?sici=0002-8282\%28197412\%2964\%3A6\%3C851\%3AOTIOCF\%3E2.0.CO\%3B2-E
}

\section{${ }^{3}$ Informational Asymmetries, Financial Structure, and Financial Intermediation}

Hayne E. Leland; David H. Pyle

The Journal of Finance, Vol. 32, No. 2, Papers and Proceedings of the Thirty-Fifth Annual Meeting of the American Finance Association, Atlantic City, New Jersey, September 16-18, 1976. (May, 1977), pp. 371-387.

Stable URL:

http://links.jstor.org/sici?sici=0022-1082\%28197705\%2932\%3A2\%3C371\%3AIAFSAF\%3E2.0.CO\%3B2-E

\footnotetext{
${ }^{3}$ Informational Imperfections in the Capital Market and Macroeconomic Fluctuations Bruce Greenwald; Joseph E. Stiglitz; Andrew Weiss The American Economic Review, Vol. 74, No. 2, Papers and Proceedings of the Ninety-Sixth Annual Meeting of the American Economic Association. (May, 1984), pp. 194-199. Stable URL: http://links.jstor.org/sici?sici=0002-8282\%28198405\%2974\%3A2\%3C194\%3AIIITCM\%3E2.0.CO\%3B2-1
}

\section{References}

NOTE: The reference numbering from the original has been maintained in this citation list. 
http://www.jstor.org

\section{LINKED CITATIONS}

- Page 2 of 2 -

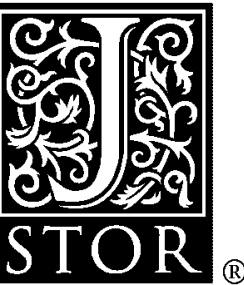

\section{Informational Imperfections in the Capital Market and Macroeconomic Fluctuations}

Bruce Greenwald; Joseph E. Stiglitz; Andrew Weiss

The American Economic Review, Vol. 74, No. 2, Papers and Proceedings of the Ninety-Sixth Annual Meeting of the American Economic Association. (May, 1984), pp. 194-199.

Stable URL:

http://links.jstor.org/sici?sici=0002-8282\%28198405\%2974\%3A2\%3C194\%3AIIITCM\%3E2.0.CO\%3B2-1

\section{Informational Asymmetries, Financial Structure, and Financial Intermediation}

Hayne E. Leland; David H. Pyle

The Journal of Finance, Vol. 32, No. 2, Papers and Proceedings of the Thirty-Fifth Annual Meeting of the American Finance Association, Atlantic City, New Jersey, September 16-18, 1976. (May, 1977), pp. 371-387.

Stable URL:

http://links.jstor.org/sici?sici=0022-1082\%28197705\%2932\%3A2\%3C371\%3AIAFSAF\%3E2.0.CO\%3B2-E

\section{A Re-Examination of the Modigliani-Miller Theorem}

Joseph E. Stiglitz

The American Economic Review, Vol. 59, No. 5. (Dec., 1969), pp. 784-793.

Stable URL:

http://links.jstor.org/sici?sici=0002-8282\%28196912\%2959\%3A5\%3C784\%3AAROTMT\%3E2.0.CO\%3B2-9

\section{On the Irrelevance of Corporate Financial Policy}

Joseph E. Stiglitz

The American Economic Review, Vol. 64, No. 6. (Dec., 1974), pp. 851-866.

Stable URL:

http://links.jstor.org/sici?sici=0002-8282\%28197412\%2964\%3A6\%3C851\%3AOTIOCF\%3E2.0.CO\%3B2-E

\section{Credit Rationing in Markets with Imperfect Information}

Joseph E. Stiglitz; Andrew Weiss

The American Economic Review, Vol. 71, No. 3. (Jun., 1981), pp. 393-410.

Stable URL:

http://links.jstor.org/sici?sici=0002-8282\%28198106\%2971\%3A3\%3C393\%3ACRIMWI\%3E2.0.CO\%3B2-0

\section{Incentive Effects of Terminations: Applications to the Credit and Labor Markets}

Joseph E. Stiglitz; Andrew Weiss

The American Economic Review, Vol. 73, No. 5. (Dec., 1983), pp. 912-927.

Stable URL:

http://links.jstor.org/sici?sici=0002-8282\%28198312\%2973\%3A5\%3C912\%3AIEOTAT\%3E2.0.CO\%3B2-F

NOTE: The reference numbering from the original has been maintained in this citation list. 